\title{
ДЕЯКІ ПРОБЛЕМИ МОРФОЛОГІЇ У СВІТЛІ НАУКОВОЇ КОНЦЕПЦІЇ С. І. ДОРОШЕНКА
}

Своєрідність дієприслівника як морфологічної одиниці мови породжувала й породжує наукові дискусії навколо нього, зокрема в полі неослабної уваги науковців перебуває визначення його частиномовної віднесеності. Мета статті - з'ясувати погляди професора С. І. Дорошенка на цей клас слів. Наукова розвідка виявила оригінальне бачення вченого синтаксичних, семантичних, морфологічних і дериваційних ознак дієприслівника, що дало підстави С. І. Дорошенку підтримати тих мовознавців, які висловилися за надання дієприслівнику статусу окремої частини мови.

Ключові слова: дієприслівник, частина мови, гетерогенна класифікація частин мови, ознаки дієприслівника.

Oleksenko O. A. Some Problems of Morphology in the Aspect of S. I. Doroshenko's Scientific Ideas. The peculiarity of the diiepryslivnyk (participle) as a morphological unit of language generates scientific discussions, in particular, in the field of scientists' constant attention there is a definition of its part-language affiliation. Linguists in their approaches to determine the place of the diiepryslivnyk in the morphological system of the Ukrainian language are divided into three groups. The first one is made up of those who consider the adverb to be the hybrid adverbial-verbal category, which is one of the forms of the verb, but has the potential to adverbialize. The second group includes those researchers who consider the diiepryslivnyk as a separate, independent part of the language that has features as verb and adverb, and their own semantic and grammatical marks. The third approach, common to modern grammatists, which include diiepryslivnyk to adverbs, regards it as a verbal adverb, emphasizing the verbaid character of this class of words. The aim of the article is to elucidate the views of Professor Doroshenko on this class of words. Speaking about the lexical meaning of the adverb, the scientist argues that although it has an verbal basis, but the meaning does not correspond to the verb, because it is transformed in accordance with its syntactic function - the procedural circumstance, and this is the specificity of the semantics of the diiepryslivnyk. Scientific research revealed the scientist's original vision as for the syntactic, semantic, morphological and derivative features of the diiepryslivnyk, which gave the reason S. I. Doroshenko to support those linguists who speak in favor of giving the diiepryslivnyk the status of a separate part of speech.

Key words: diiepryslivnyk, part of speech, heterogeneous classification of parts of speech, features of the diiepryslivnyk.

У науковому доробку С. I. Дорошенка, присвяченому питанням граматики, проблеми морфології займають не так багато місця, оскільки основна увага науковця зосереджувалася на синтаксисі. Однак дієприслівнику пощастило, напевне, через те, що його граматичні ознаки безпосередньо пов'язані з характером функціювання в реченні, морфологічні риси тісно переплетені з синтаксичними можливостями.

Розглянемо одну невеличку статтю професора «До питання про граматичний статус дієприслівника» (Дорошенко, 2009: 36 - 39), яка послужила відправною точкою, стала поштовхом для кількох досліджень його аспірантів.

Відомо, що мовознавці за своїми підходами до визначення місця дієприслівника в морфологічній системі мови поділяються на три групи. 
Першу становлять ті, хто визнає дієприслівник гібридною прислівниководієслівною категорією, яка входить до числа форм дієслова, але має потенційну здатність до адвербіалізації. Цю ідею В. В. Виноградова, яка у свою чергу грунтується на поглядах О. Павловського, в україністиці підтримує В. М. Русанівський, А. П. Грищенко, В. О.Горпинич, О. О. Селіванова та ін. До другої групи належать ті дослідники, які вважають дієприслівник окремою, самостійною частиною мови, що має ознаки як дієслова і прислівника, так і свої власні семантико-граматичні орієнтири. Ця думка була висловлена О. М. Пєшковським, підтримана Д. М. Овсянико-Куликовським, а пізніше розвинута в працях В. В. Бабайцевої і Л. Д. Чеснокової, в українському мовознавстві вона підтримана С. І. Дорошенком і Л. К. Лисак. Третій підхід, поширений серед сучасних граматистів, має в основі концепцію В. О. Богородицького, який відносив дієприслівники до прислівників. I. Р. Вихованець, підкреслюючи вербоїдний характер цього класу слів, розглядає його як віддієслівний прислівник. Так само його класифікують К. Г. Городенська, А. П. Загнітко, І. К. Кучеренко та їхні наукові послідовники.

Неузгодженість в оцінці морфологічної сутності дієприслівника породжує й неоднозначні погляди на його граматичні ознаки.

Погляди C. I. Дорошенка загрунтовані на триєдиному гетерогенному підході до класифікації частин мови: своєрідності семантики класу слів (спільне категоріальне значення), особливих морфологічних ознаках (морфологічних категоріях), самостійній (оригінальній) синтаксичній функції, а також з урахуванням словотвірних особливостей дієприслівника.

Так, С. I. Дорошенко найперше акцентує увагу на особливій синтаксичній функції дієприслівника - обставині, зазначаючи, що дієслово, якщо вважати дієприслівник формою дієслова, по своїй суті не може виконувати функцію обставини. I саме синтаксичною залежністю дієприслівника від присудка чи іншого члена з ознаками процесуальності вчений пояснює можливості часової семантики дієприслівника: попередності, одночасності й наступності стосовно абсолютного часу предиката. Якщо фінітне дієслово має форму вираження часу, то дієприслівник такої форми не має, форми на -ЧИ, -ШИ не протиставляються як часові, оскільки не пов'язані з вираженням теперішнього, минулого й майбутнього граматичного часу. Учений таким чином висновковує, що дієприслівнику властивий відносний час як окрема мовна категорія, не тотожна граматичному часу. I цей висновок видається абсолютно логічним. «А оскільки дієприслівник не має граматичної категорії часу, то й не може виступати в предикативній функції, адже ця функція існує в нерозривній єдності двох граматичних категорій - часу і способу (Дорошенко, 2009: 37). Термін напівпредикативність, вживаний до синтаксичних можливостей дієприслівника, науковець вважає неприйнятним через непевність змісту.

Говорячи про лексичне значення дієприслівника, учений стверджує, що хоча він і має дієслівну основу, але значення не відповідає дієслівному, бо трансформується відповідно до його синтаксичної функції - процесуальної обставини, у цьому й полягає специфіка семантики дієприслівника. 
C. I. Дорошенко не відкидає здатність дієприслівника мати категорію виду, стану, перехідності/неперехідності, проте їхні граматичні значення не становлять у дієприслівника граматичної опозиції, оскільки вони успадковані від твірного дієслова і $€$ «відголоском семантики і морфологічної будови дієслова, від якого він утворився», а тому не можуть вважатися визначальними морфологічними рисами дієприслівника.

Єдине, що викликає в нас роздуми, так це категорія стану. Науковець зазначає, що «відмінність активного і пасивного станів завдячує словотворчим засобам» (Дорошенко, 2009: 38), тобто береться до уваги, власне, від зворотних чи незворотних дієслів утворено дієприслівник. Тобто С. І. Дорошенко, як і багато вчених, у поглядах на категорію стану виходить із того, що пасивний стан утворюється від перехідних дієслів за допомогою постфікса -СЯ і протиставлення зберігається саме в такій опозиції: перехідні дієслова активного стану - неперехідні з постфіксом -СЯ пасивного стану. Якщо навіть так вузько розуміти категорію стану (В. М. Русанівський, М. А. Жовтобрюх так само), а всі інші дієслова вважати позастановими, то на практиці не можна утворити жодного речення, де б дієприслівники мали ознаки пасивного стану, оскільки значення логічного суб'єкта і об'єкта, закладене в дієприслівник, і значення логічного суб'єкта і об'єкта фінітного дієслова мають збігатися (Завдання виконуються студентами, записавши (чи записавшись) у зошит - конструкція неправильна як і Студенти виконують завдання, записавшись ними у зошит). Отже, дієприслівники ніколи не виражають пасивного стану, а тому без кореляції з ним не можна стверджувати і про існування в дієприслівниках активного стану. Швидше за все, С. І. Дорошенко мав на увазі успадковану не категорію стану, а семантику зворотності/ незворотності дії.

Категорично проти був мовознавець і щодо віднесення дієприслівників до прислівників, вважаючи, що дієприслівники, на відміну від прислівників, здатні мати залежні слова, створюючи синтаксичні звороти. До того ж, на противагу прислівникам, дієприслівник передає процесуальну ознаку дії.

Учений стверджує, що дієприслівник - самостійна частина мови, бо 1) утворений від дієслівної основи і не втрачає ознак перехідності/неперехідності, виду, стану і властивості мати залежні слова; 2) має дериваційні особливості - суфікси -ЧИ, -ШИ, не пов'язані з розрізненням часу і виду; 3) дієприслівник наділений відносним часом; 4) у реченні дієприслівник виступає процесуальною обставиною, його семантика чітко не визначена; 5) дієприслівники утворюють разом із залежними словами синтаксичні звороти (на відміну від фінітних дієслів і прислівників).

Із таким поглядом С. І. Дорошенка можна погоджуватися чи не погоджуватися, але він заслуговує на повагу як погляд людини, наділеної глибиною наукової думки, здатністю мислити креативно, не боячись порушити стан спокою в лінгвістичній науці, прагнучи докопатися до найпотаємніших закутків граматики. 


\section{ЛІТЕРАТУРА}

1. Дорошенко С. І. До питання про граматичний статус дієприслівника. Наукові простори: вибрані праці. Харків: «Нове слово», 2009. С. 36 - 39. 2. Дорошенко С. I. Одиничні дієприслівники і дієприслівникові звороти як елементи образної системи мови. Наукові простори: вибрані праці. Харків: «Нове слово», 2009. С. 168 - 171. 3. Лисак Л. К. Синтаксико-стилістичні функції речень з дієприслівником у стилях сучасної української мови: Автореф. дис...канд. філол. наук: 10.02.01 / ХНПУ ім. Г.С. Сковороди. Харків, 2007. 4. Олексенко О. А. Дієприслівник у проекції категорії стану. Лінгвістичні дослідження: Зб. наук. праць. Харків: ХНПУ ім. Г.С. Сковороди, 2017. Вип. 46. С. $80-85$.

\section{REFERENCES}

1. Doroshenko, S. I. (2009). Do pytannia pro gramatychnyi status diiepryslivnyka [To the Grammatical Status of Diiepryslivnyk (Participle) ]. Kharkiv [in Ukrainian]. 2. Doroshenko, S. I. (2009). Odynychni diiepryslivnyky i diiepryslivnykovi zvoroty yak elemennty obraznoii systemy movy [Diiepryslivnyks (Participles) and Diiepryslivnyk Phrases as Elements of a Figurative System of Language ]. Kharkiv [in Ukrainian]. 3. Lysak, L. K. (2007). Syntaksyko-stylistychni funktsii rechen z diiepryslivnykom u styliakh suchasnoi ukrainskoi movy [Syntactic-Stylistic Functions of Sentences with an Diiepryslivnyk (Participle) in the Functional Styles of the Modern Ukrainian Language]. Kharkiv [in Ukrainian]. 4. Oleksenko, O. A. (2017). Diiepryslivnyk u proektsii kategorii stanu [Diiepryslivnyk (Participle) Viewed through the Category of Voice System ]. Kharkiv [in Ukrainian].

Олексенко Олена Андріївна - кандидат філологічних наук, професор, завідувач кафедри української мови, Харківський національний педагогічний університет імені Г.С. Сковороди; вул. Валентинівська, 2, Харків, 61168, Україна.

Tel. +380972896846

E-mail: oleksenkoolena@gmail.com

http://orcid.org/0000-0002-6541-8040

Oleksenko Olena Andriivna - PhD in Philology, Professor, Head of the Ukrainian Language Department, H.S. Skovoroda Kharkiv National Pedagogical University; Valentynivska Str., 2, Kharkiv, 61168, Ukraine.

Надійшла до редакції 19 березня 2019 року 